\title{
A CENTURY OF X-RAY CRYSTALLOGRAPHY AND 2014 INTERNATIONAL YEAR OF X-RAY CRYSTALLOGRAPHY
}

\author{
Biserka Kojić-Prodić \\ Rudjer Bošković Institute, Bijenička c. 54, Zagreb, Croatia \\ kojic@irb.hr
}

The $100^{\text {th }}$ anniversary of the Nobel prize awarded to Max von Laue in 1914 for his discovery of diffraction of X-rays on a crystal marked the beginning of a new branch of science - X-ray crystallography. The experimental evidence of von Laue's discovery was provided by physicists W. Friedrich and P. Knipping in 1912. In the same year, W. L. Bragg described the analogy between X-rays and visible light and formulated the Bragg's law, a fundamental relation that connected the wave nature of X-rays and fine structure of a crystal at atomic level. In 1913 the first simple diffractometer was constructed and structure determination started by the Braggs, father and son. In 1915 their discoveries were acknowledged by a Nobel Prize in physics. Since then, X-ray diffraction has been the basic method for determination of three-dimensional structures of synthetic and natural compounds. The three-dimensional structure of a substances defines its physical, chemical, and biological properties. Over the past century the significance of X-ray crystallography has been recognized by about forty Nobel prizes. X-ray structure analysis of simple crystals of rock salt, diamond and graphite, and later of complex biomolecules such as B12vitamin, penicillin, haemoglobin/myoglobin, DNA, and biomolecular complexes such as viruses, chromatin, ribozyme, and other molecular machines have illustrated the development of the method. Among these big discoveries the double helix DNA structure was an epochal achievement of the $20^{\text {th }}$ century. These discoveries, together with many others of the X-ray crystallography, have completely changed our views and helped to develop other new fields of science such as molecular genetics, biophysics, structural molecular biology, material science, and many others. During the last decade, the implementation of free electron X-ray lasers, a new experimental tool, has opened up femtosecond dynamic crystallography. This highly advanced methodology enables to solve the structures and dynamics of the most complex biological assemblies involved in a cell metabolism. The advancements of science and technology over the $20^{\text {th }}$ and $21^{\text {st }}$ centuries are of great influence on our views in almost all human activities. The importance of Xray crystallography for science and technology advocates for its high impact on a wide area of research and declares it as a highly interdisciplinary science. In short, crystallography has defined the shape of the modern world.

Focusing on single crystal diffraction, this essay tackles only one field of crystallography; the comprehensive review on X-ray crystallography can hardly be fitted into a single article. The aim with this review was to highlight the most striking examples illustrating some of the milestones over the past century.

Keywords: centennial anniversary of X-ray crystallography; discovery of X-ray crystallography - dazzling history; highlights; $\mathrm{X}$-ray structure analysis and its prospect

\section{СТОГОДИШНИНАТА ОД РЕНДГЕНСКАТА КРИСТАЛОГРАФИЈА И ИНТЕРНАЦИОНАЛНАТА 2014 ГОДИНА НА РЕНДГЕНСКАТА КРИСТАЛОГРАФИЈА}

Стогодишнината од доделувањето на Нобеловата награда на Макс фон Лауе (Max von Laue) во 1914 година за откривањето на дифракцијата на рендгенските зраци од кристал, го означи почетокот од новата гранка на науката - рендгенската кристалографија. Експериментален доказ на

\footnotetext{
- Dedicated to Academician Gligor Jovanovski on the occasion of his $70^{\text {th }}$ birthday.
} 
Фон Лауевото откритие беше добиен од физичарите В. Фридрих (W. Friedrich) и П. Книпинг (Р. Knipping) во 1912 година. Истата година, В. Л. Брег (W. L. Bragg) ја опиша аналогијата помеѓу рендгенските зраци и видливата светлина и го формулираше Бреговиот закон, фундаменталната равенка која ги поврзува брановата природа на рендгенските зраци и фината структура на кристалот на атомско ниво. Во 1913 година беше конструиран првиот едноставен дифрактометар и стартуваше определувањето на кристалната структура од страна на Брегови, таткото и синот. Во 1915 година за нивните откритија тие добија Нобелова награда по физика. Оттогаш, рендгенската дифракција стана основна метода за определување на тридимензионалните структри на синтетичките и природните соединенија. Тридимензионалната структура на супстанците ги дефинира нивните физички, хемиски и биолошки својства. Во текот на изминатиот стогодишен период важноста на рендгенската кристалографија е потврдена со доделување на над четириесет Нобелови нагрди од ова подрачје. Рендгенската структурна анализа на едноставните кристали од готварска сол, дијамант и графит, а подоцна на комплексните биомолекули како што се витаминот В12, пеницилинот, хемоглобинот/миоглобинот, ДНК и биомолекуларните комплекси како што се вирусите, хроматинот, рибозомите и други сложени молекули, го илустрираше развојот на оваа метода. Помеѓу сите овие откритија, двојниот хеликс на структурата на ДНК беше епохалното откритие на 20-иот век. Овие откритија, заедно со многу други од областа на рендгенската кристалографија, комплетно ги сменија нашите видици и помогнаа да се развијат многу други подрачја на науката, како што се, на пример, молекуларната генетика, биофизиката, структурната молекуларна биологија, науката за материјалите и многу други. Во текот на последната деценија, со новата експериментална метода заснована на имплементацијата на слободни електрони на рендгенските ласери, се лансираше фемтосекундната динамичка кристалографија. Оваа високо напредната методологија овозможува да се реши структурата и динамиката на најкомплексните биолошки системи вклучени во ќелијниот метаболизам. Напредокот на науката и технологијата во текот на 20-иот и почетокот на 21-иот век се од големо значење за ширење на нашите видици во речиси сите области на човековите активности. За важноста на рендгенската кристалографија за науката и технологијата сведочи нејзиното високо влијание врз другите полиња на истражување, етаблирајќи се како високо интердисциплинарна наука. Со еден збор, кристалографијата го има дефинирано ликот на модерниот свет.

Фокусирајќи се на дифракцијата на монокристал, овој текст се однесува само на едно подрачје на кристалографијата, затоа што сеопфатен преглед на рендгенската кристалографија тешко би можел да се смести во еден труд. Целта на овој преглед е да ги потенцира најзначајните примери кои илустрираат некои од пресвртните моменти во изминатото столетие.

Клучни зборови: стогодишнина од рендгенската кристалографија; откривање на рендгенската кристалографија - вртоглава историја; најважни случувања; рендгенска структурна анализа и нејзини перспективи

\section{INTRODUCTION}

The United Nations declared 2014 as International Year of Crystallography to celebrate the centenary of the discovery of X-ray crystallography and to emphasize the global importance of crystallography in many aspects of human life; the General Assembly of UN declared that special event on July 15, 2012 by the proposition of UNESCO and the International Union of Crystallography (IUCr). The opening ceremony of the International Year of Crystallography was held in Paris on 20 and 21 January 2014 followed by numerous activities around the world. The International Year of Crystallography commemorates the centennial of the birth of X-ray crystallography, based on the discoveries of Max von Laue and the family tandem - father and son, William Henry and William Lawrence Bragg. Both discoveries were awarded Nobel prizes in 1914 and 1915. The year
2014 also commemorates the $50^{\text {th }}$ anniversary of the Nobel Prize awarded to Dorothy Hodgkin for her work on vitamin B12 and penicillin, and also the 80th anniversary of macromolecular crystallography marked by the first X-ray photograph of enzyme pepsin recorded in 1934 by J. D. Bernal and D. Hodgkin.

X-ray crystallography is the leading method for the determination of molecular and crystal structures of any crystalline material of natural or synthetic origin. The molecular structure defines the three dimensional arrangements of atoms connected by intramolecular - covalent or other (ionic, metal) interactions, which are responsible for physical and chemical properties of each compound. The crystal structure is defined by the periodic arrangement of molecules, which are held together by intermolecular interactions. These forces are responsible for physical properties of crystals. Xray crystallography provides crucial information 
for many different areas of science and technology. The double helix structure of DNA molecule determined by X-ray crystallography was the epochal discovery of the $20^{\text {th }}$ century. Molecular genetics and related disciplines emerged from that discovery. X-ray crystallography has revolutionized our understanding of molecular biology and has assisted in development of molecular medicine and new drugs. Design of catalysts essential in syntheses of various compounds based on the principals of 'green' chemistry within the context of sustainable ecology, is on the front line of chemical crystallography. The preparation of a wide selection of novel materials such as alloys, ceramics, fibres, plastic materials, detergents, design of systems for production of 'green energy' such as batteries, fuel and solar cells is guided by structural characterization by X-ray diffraction of materials used in these technologies. On the front lines of novel materials are magnetic materials, materials for molecular electronics, and potential materials for quantum computers, being at present close to a science fiction. X-ray crystallography has been also established as a method of choice in geosciences including mineralogy, as well as in archaeology. The involvement of X-ray crystallography in all these fields of science and technology advocates for its high impact on a wide area of research and declares it as a highly interdisciplinary science. In short, crystallography defines the shape of our modern world.

The advancement of technology and computer facilities supported by efficient software has contributed enormously to improve and optimize the experiments of X-ray diffraction. The most significant breakthrough has been achieved in the area of X-ray sources using synchrotrons in the 1970 s and most recently by the advent of the freeelectron lasers (XFEL). The sophisticated equipment has speed up experiments providing more accurate data. As the results of these wonders of technology, more three-dimensional structures have become available. Storing huge number of data necessarily led to the formation of databases such as Cambridge Structural Data Base (CSD, with over 750,000 entries http://www.ccdc.cam. ac.uk), Protein Data Bank (PDB, with over 100,000 entries, http://www.rcsb.org/pdb/home/ home.do), Metals, Alloys and Intermetallic Data Base (CRYSMET, with over 126,000 entries), Inorganic Crystal Structure Database (ICSD, with over 173,000 entries, http://icsd.fiz-karlsruhe.de) and Powder Diffraction File (http://www.icdd. $\operatorname{com} /$ ), and other essential resources of crystallographic information.

\section{DAZZLING HISTORY}

Goethe's quote "The history of science is science itself" could offer a simple chronological approach starting from the studies of crystal morphology marvelled by Pliny the Elder (AD 23 to 79) who described the faces of quartz crystals. These observations were followed by more complex discoveries. On a historical route, for instance, one would enjoy reading the interesting papers of Pierre Curie on crystallography and symmetry, as well as about physical properties of crystals such as piezoelectricity and magnetism. However, such an approach would be extensive and probably miss to point out the highlights that put forward the Xray crystallography as a central method to many disciplines and different areas of science. To learn the history of crystallography, there is no need to strictly separate crystallography from mineralogy, chemistry, biology, physics; it should be understood in synergy with these sciences that change drastically the basic concepts through close interactions among them and opening new approaches. "After all, are there the true boundaries between sciences? May be the boundaries of a science, as they are established, represent only artificial constructions adapted to current understanding" [1].

Inspired by Maxwell's theory of electromagnetic waves, at the University of Würzburg, on November 8, 1895 W. C. Röntgen discovered radiation of unknown origin and properties, which he called X-rays [2]. The shadowgraph of a hand skeleton of his wife Bertha, taken on December 22, 1895 , had circulated quickly all over the world, as it did hundred years later at its centennial anniversary. The discovery gained enormous publicity because everybody realized the power of X-rays to reveal "the architecture of invisible". The world realized the importance of Röntgen's discovery and the first Nobel Prize for physics was awarded to him in 1901. The nature of X-rays was not known at that time. Seventeen years after Röntgen's discovery, Max von Laue suggested that Xrays can be scattered or diffracted by a crystal [3] which was confirmed by an experiment aiming to resolve controversy over the nature of X-rays [4]. The experiments revealed its wave nature and confirmed Laue's idea for which he won the Noble Prize in 1914 (Fig. 1). A new branch of science based on that discovery saw the dawn in November 1912, when the 22-year old Lawrence Bragg interpreted the complicated pattern of Laue's photograph. He applied very simple idea coming from the optics of visible light that $\mathrm{X}$-rays are reflected from the atomic planes in the crystal - the Bragg's law $[5,6]$. W. H. Bragg built the first spectrometer, 
which enabled structure determinations of some minerals, such as diamond [7] and table salt [8]. The most striking idea in that area, put forward in 1915 by W. H. Bragg [9] involved the representation of the periodic repeat of atomic patterns in a crystal by Fourier series. This mathematical formulation was a milestone in X-ray structure analysis. In 1915 the Nobel Committee recognized the great discovery of the Braggs and awarded them a prize. At the very beginning and through the next hundred years the high significance of X-ray crystallography has been confirmed by a number of Nobel prizes.
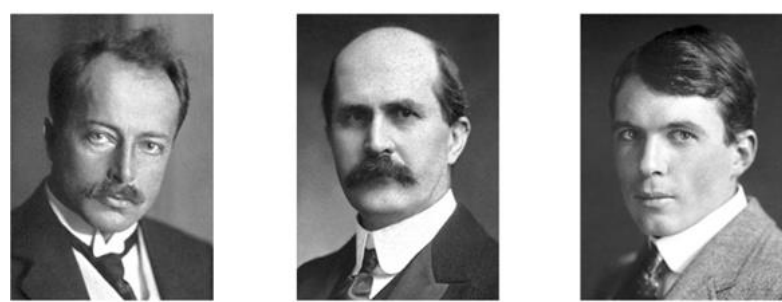

Fig. 1. Nobel laureates for physics (from left to right): 1914 Max von Laue, 1915 William Henry Bragg (father) and William Lawrence Bragg (son).
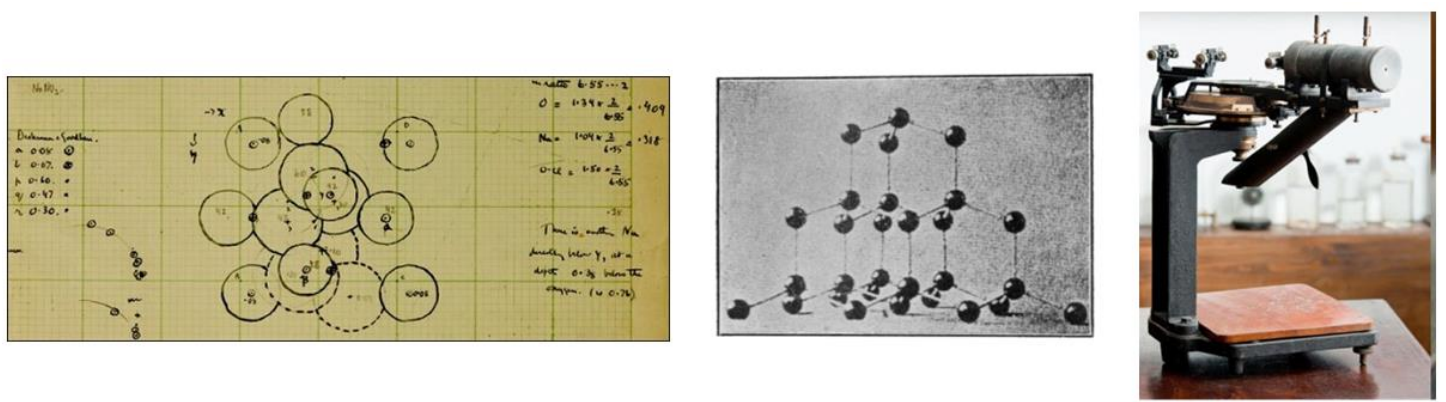

Fig. 2. (Left) A page from W. H. Bragg's notebook. (Centre) Structural model of diamond. (Right) The first instrument used in X-ray diffraction experiments performed by the Braggs for determination of crystal structures (exposed in a foyer of Department of Physics and Astronomy, The University of Leeds).

\section{ADVANCED AND NEW METHODS AND TECHNOLOGIES SUPPORTING THE DEVELOPMENT OF X-RAY CRYSTALLOGRAPHY}

The basic theoretical knowledge of X-ray crystallography was already known around the 1920s. The tremendous progress of the X-ray crystallography is based on the use of powerful computers, utility of on-line experiments such as robotic machines for crystallization, controlled data collection and processing, interpretation of Fourier maps, refinement of an experimentally derived model of the structure, visualization of the threedimensional structure and modelling using computer graphics, handling databases (data mining and cloud computing) for structure systematics and predictions, and study of protein folding and structure-activity correlations [10 and references therein, 11, 12].

For determination of macromolecular structures, more intense sources of high brilliance and high degree of collimation are required for data collection. Some advancement in this respect has been made by the use of rotating anode tubes, but a significant step forward was achieved by the first exploitation of synchrotron X-ray radiation in the late seventies of the last century. The constant progress of technology has led to a more intense monochromatic beam of high brilliance and collimation (of $50 \mu \mathrm{m}$ in diameter), suitable for very small, weakly diffracting samples, as well as for very large unit cells, or unstable crystals using cryotechniques. An additional experimental advantage of such sources is the wavelength tunability, which makes it possible to use the method of multiwavelength anomalous dispersion (MAD) over a wide range of atomic absorption edges for phase determination of structure factors. By virtue of such powerful X-ray sources it is also possible to perform time-resolved experiments, e.g. using polychromatic radiation on stationary crystals producing Laue patterns. This idea might seem paradoxical to the basic concept of X-ray crystallography. In general, X-ray crystallography reveals only the space-averaged structure over all molecules in the crystal for the time of exposure to the X-ray beam. However, with time-resolved crystallography using a polychromatic synchrotron beam and a stationary crystal, and an exposure time about three-order of magnitude shorter than that of monochromatic experiments, ultrafast experiments became possible. In reality, it was possible to record a series of events thanks to powerful sources and fast and sen- 
sitive detectors, and smart software. The approach allowed in situ studies of enzymatic activity at a nanosecond time scale [13].

Technical developments of the equipment (pixel detectors), advanced software and exponenttial growth in computing power and especially better and brighter X-ray sources, are of great impact also on electron density studies. However, the use of synchrotron radiation in this field came just recently, whereas neutron diffraction has been in use much longer in this field [14]. Specifically designed refinement procedure based on atomcentered multipole models [15-17] was a significant step forward. The electron maps obtained by using such data treatment reveal fine details about the electronic structure and its modifications, influenced by partners connected by the chemical bond or participating in intermolecular interactions. Charge-density studies can reveal an overlap between atomic orbitals, lone pairs, the bending of bonds in strained rings, $\pi$-interactions, polarization effects, deformation of electron density in intermolecular interactions, particularly in hydrogen bonds. Understanding the nature of non-covalent interactions is essential for revealing the secrets of molecular assemblies in molecular biology (molecular machines such as ribozyme, photosystems I and II, and viruses), in novel functional materials, and also in synthetic chemistry, particularly in supramolecular chemistry using the crystal engineering approach [18].

As the method of electron density studies stands today, fine details match well the pictures obtained by theoretical ab initio quantum mechanical calculations. However, the significant breakthrough was achieved recently by combination of the results coming from different experiments using $\mathrm{X}$-ray, neutron and polarized neutron diffracttion data on spin resolved electron density [19]. These experimental spin up and spin down densities compare well with density functional theory (DFT).

At present the development of the X-ray free electron lasers (XFEL) is a monumental technical achievement, which definitely opens up a new era - serial femtosecond crystallography ( $<70 \mathrm{fs})$ allowing to record ultrafast movies of (bio)chemical reactions and to understand their dynamics. Incredibly intense, ultrafast pulses of X-rays with up to $10^{13}$ photons for duration of tens of femtoseconds are used (Fig. 3). Also, these destructive pulses overcome the problems of radiation damage in protein crystallography without the need to resort to the cryotechnique which is common in use of synchrotron sources. X-ray FEL ultrafast pulses terminate before significant atomic motion can occur and the sample is unaffected.

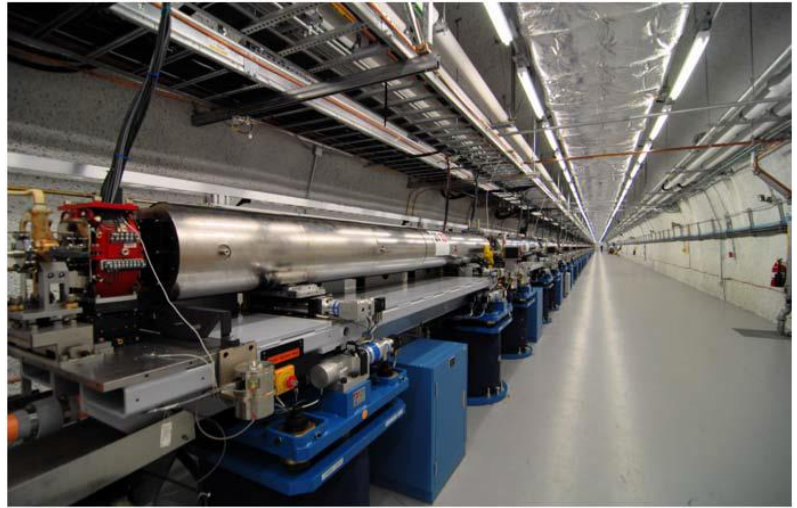

Fig. 3. Part of the beam line in the Stanford Linear Accelerator Centre (SLAC) with Linac coherent light source.

At the end of $100 \mathrm{fs}$ pulse, the average displacement of atoms is less than $1 \AA$ (experimental details described by H. N. Chapman) [20, 21]. Thus, it is possible to collect data at doses of 3 gigagray at room temperature, which is over 3000 times the conventional tolerable room-temperature dose. Such a method is suitable to obtain diffraction of nano-sized crystals. Extremely small crystals in suspension can be injected into a pulse and used for diffraction experiments. As each pulse vaporises the sample, it is necessary to replenish the sample for the next pulse, arriving at a rate of $120 \mathrm{~Hz}$. The shower of randomly oriented small crystals is provided by a microjet into beam path. By using very fast and sensitive detectors, about 120 diffraction frames per second can be collected (Fig. 4). During the experiment millions of frames are collected from which hundreds of thousands of individual snapshot diffraction patters are extracted.

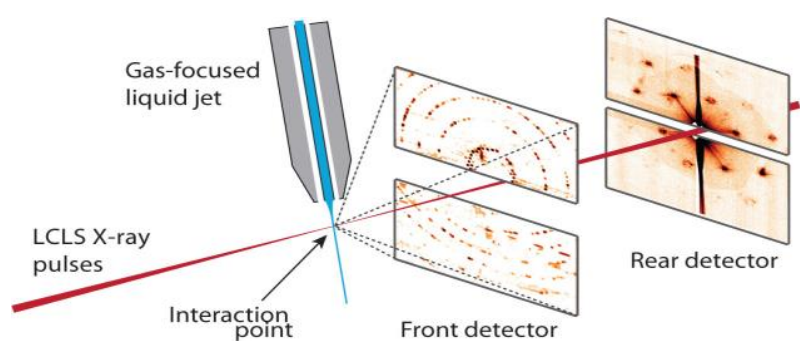

Fig. 4. A simple scheme of experiment in serial femtosecond crystallography (Chapman, 2013) [20]. Diffraction with ultrafast pulses is recorded prior to radiation damage and a roomtemperature experiment is used.

The very complex software, CrystFEL, is used to process diffraction data. The advantages of the technique are already exploited for structure determination of huge macromolecular assemblies such as photosystem I and photosystem II and numerous membrane proteins that are very flexible 
and difficult to crystallize in a size suitable for structure determination by the classical methods of macromolecular crystallography.

In addition to above described experiment with X-ray free electron lasers, they can be used in de novo phasing for determination of structure factor phases exploiting an anomalous dispersion. It is possible to use the signal of native sulphur atom $(7.3 \mathrm{keV})$ in determination of a protein structure.

The XFEL method can be used in studies of ultrafast dynamics in the microscopic world following the movement of atoms and molecules and their interaction at femto- and pico-second time scales. Such method is essential in understanding most of the macroscopic processes in physics, chemistry and biology. Ahmed Zewail already used the laser techniques to study transition states in some chemical reactions almost two decades ago and his scientific achievements were rewarded by the Nobel Prize in 1999.

\section{HIGHLIGHTS OF X-RAY CRYSTALLOGRAPHY}

The very beginning of X-ray crystallography, a part of dazzling history, was marked by two Nobel prizes, and a tradition has continued over the century to the present day with glorious discoveries winning about forty Nobel prizes. However, the choice has to be made and priority has to be given to those, which revolutionized our views in many areas of science. According to one of the founders of X-ray crystallography, W. L. Bragg, "the development of X-ray crystallography since 1912 has more than fulfilled our early expectations. It not only has revealed the way atoms are arranged in many diverse forms of matter, but also has cast a flood of light on the nature of the forces between atoms and the large-scale properties of matter. In many cases, new knowledge has led to a fundamental revision of ideas in other branches of science" [22]. The W. L. Bragg's prediction of Xray crystallography given in 1968 has been amply confirmed by the determination of many complex protein structures and their DNA/RNA assemblies including viruses, and even living cells.

The molecular topology in the crystal provides insight into the interatomic and intermolecular interactions, which determine the physical, chemical and biological properties. Let us give a few examples that illustrate how X-ray structural analysis has revealed the nature of the chemical bond. The discovery of the structure of diamond, published in 1913 revealed tetrahedrally disposed carbon atoms (Fig. 5a) and thus confirmed the as- sumption of Le Bel in 1874 [23] and Van' t Hoff in 1875 [24]. In 1891 E. Fischer [25, 26] together with A. von Bayer employed a tetrahedral concept to understand the chemistry of sugars, which led them to the problem of an optical isomerism and conformational differences. They were able to assign the relative configuration for enantiomers of various sugars and derivatives and their work established a new scientific discipline - stereochemistry. In 1949 came the evidence that, by mere chance, Fischer's assignment of glyceraldehyde was correct. J. M. Bijvoet discovered how X-ray anomalous scattering can be used to determine the absolute configuration of chiral molecules exemplified by the structure of sodium rubidium tartrate [27]. The Bijvoet method and the Barton's principle of conformational analyses accelerated the development of stereochemistry. These findings were followed by the Nobel prizes awarded to R. B. Woodward, D. H. R. Barton, O. Hassel, V. Prelog, and J. W. Cornforth for stereochemistry related researches. It became clear that molecules of life, such as amino acids, sugars, and many natural compounds, are chiral. The chiral origin of life still remains an enigma.

After the discovery of diamond followed the determinations of the structure of graphite performed by J. D. Bernal in 1924 [29] (Fig. 5b) and sixty-one years later, the third modification of carbon, fullerene (Fig. 5c) was discovered by R. F. Curl, H. W. Kroto, R. E. Smalley whom Nobel Prize in 1996 was awarded. The discovery of fullerene opened up an era of nano-materials. After eighty years of the determination of graphite structure came a sensational discovery of graphene - a single-layered network of carbon atoms, the novel functional material of great potential in different areas of applications (Fig. 5d). The significance of the work of A. Geim and K. Novoselov [30] related to graphene was recognized in 2010 by the Nobel Prize. The given examples of allotropic modifications of carbon atom clearly show the impact of different electronic structures on character of chemical bonds and thus on crystal structures and properties. There are more examples that illustrate how our perceptions are the subject to changes. Table salt, $\mathrm{NaCl}$, was treated as a molecule but after its X-ray analysis it turned to be a threedimensional array of sodium and chlorine ions held together by Coulomb interactions. One hardly can overlook structure determination of hexamethylbenzene performed by Kathleen Lonsdale in 1929 [31]; she revealed the planarity of the molecule, calculated the values of carbon bonding angles $\left(120^{\circ}\right)$ and carbon bond lengths $(1.39 \AA)$ confirming Kekulé's hypothetic model. In early days of the 
$20^{\text {th }}$ century, it was difficult to reconcile the new view of ionic compounds with the classical chemical ideas of that time. The crystal structure of penicillin, solved by D. Hodgkin in 1949 [32], revealed for the first time the presence of a four-membered $\beta$-lactam ring, unknown to organic chemists of that time. Her determination of the vitamin B-12 structure showed the existence of a metal-carbon bond and the corrinoid ligand system, not previously encountered in natural compounds. A completely new field of organometallic chemistry emerged from this finding. D. Hodgkin was the first scientist who used X-ray diffraction to determine the structure of biologically active molecules (Fig. 6). For the results of her work she won the Nobel Prize in 1964.
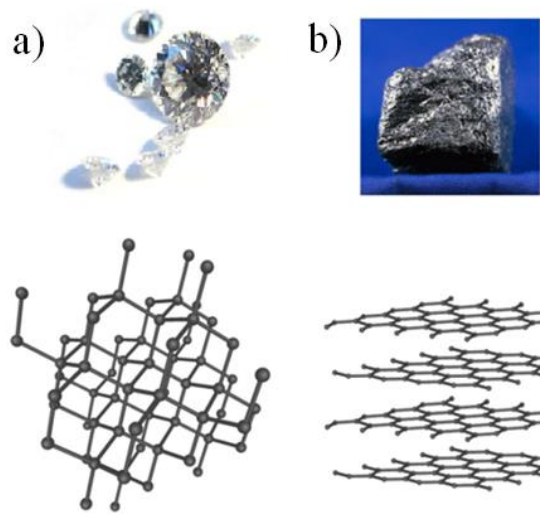

c)

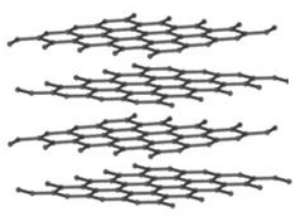

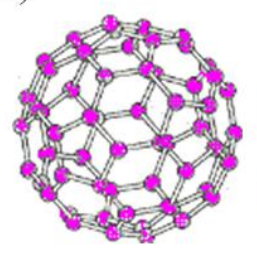

d)

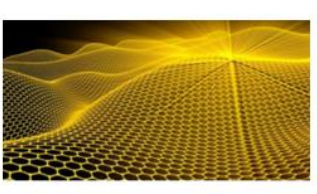

e)

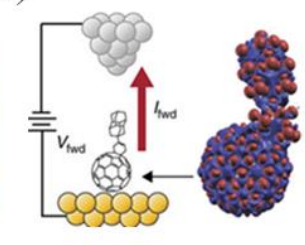

Fig. 5. a) Diamond with tetrahedral $\mathrm{Csp}^{3}$ carbon atoms; b) graphite with layered hexagonal network having the carbon $\mathrm{Csp}^{2}$ atoms; c) the fullerene molecule C60, having carbon atoms in both hybridizations, is basic nanomaterial; d) one-dimensional hexagonal network of carbon atoms - graphene is very hard with high conductivity and many other useful properties; e) hybrid material fullerene with attached diamantoid molecule, coating the (111) face of gold, conducts an electrical current in one direction (current rectification) the invention being essential in molecular electronics [28].

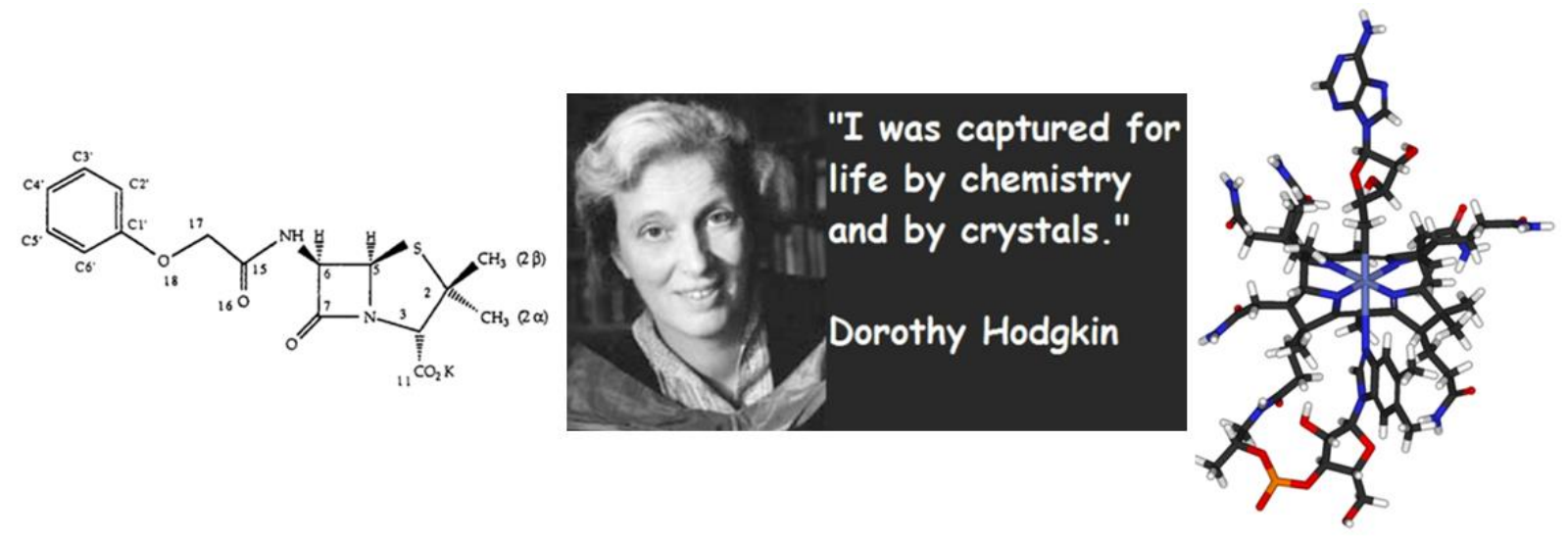

Fig. 6. The International Year of Crystallography 2014 marks the 50th anniversary of D. Hodgkin's Nobel Prize award and also 80 years of foundation of macromolecular crystallography denoted by the first X-ray photograph of pepsin recorded by D. Hodgkin and J. D. Bernal in 1934.

In early days of X-ray structure analysis, up to 1934 centrosymmetric structures were determined by 'trial and error method' due to a lack of mathematical method for determination of phases of structure factors (Fourier transform). The discovery of property of modified Fourier synthesis which allowed the determination of heavy atoms in the structure, published by L. Patterson in 1934 [33], enabled determination of noncentrosymmetric structures. As the Patterson synthesis was intro- duced in the structure analysis, an idea for determination of protein structures using heavy atom derivatives emerged. M. Perutz recorded the first diffraction photograph of haemoglobin in 1938 and prepared protein-mercury derivatives to solve the phasing problem. After years of hard work he proposed the first model of haemoglobin molecule (Fig. 7) and reported it during Cavendish seminar in 1951. It is interesting to mention that the Perutz's student F. Crick disregarded the haemoglo- 
bin structural model because he did not believe to the phasing method. In spite of that, in 1954 Perutz published the structure [34], but the refined model at the resolution $5.5 \AA$ appeared in 1960 [35]. It was used to propose the mechanism of respiration and oxygen transport in a living body. In total, Perutz's research on haemoglobin structure took over twenty years because X-ray crystallography at that time required lot of persistent work and high mental ability of a researcher. The achievements of $\mathrm{M}$. Perutz and J. Kendrew on haemoglobin and myoglobin in 1962 won the Nobel Prize. However, a contemporary method of X-ray crystallography dynamical crystallography can give insight into a mechanism of biochemical reaction and provide more detailed explanation of a respiration process.
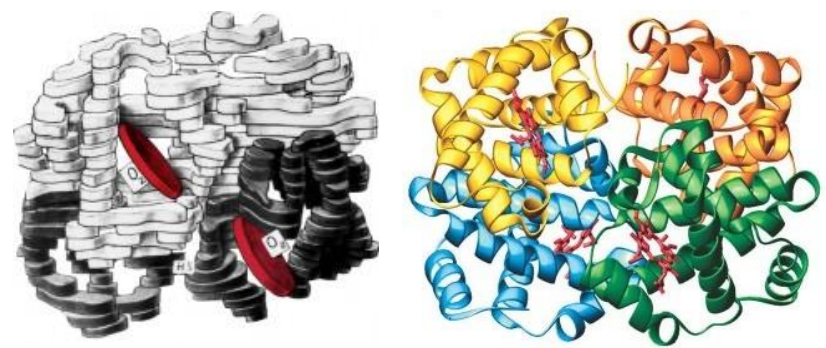

Fig. 7. Perutz's model of haemoglobin structure (left) and a contemporary presentation of refined structure (right). A prostetic group, haem with ferrous ion, positioned in a centre of a porphyrin, is shown in red.

In early fifties of the last century an epochal discovery of the structure of DNA double helix came to light. The '51-photo' of a DNA fibre recorded by Rosalind Franklin and her PhD student R. G. Gosling in 1953 [36] undoubtedly revealed helicoidal structure of a molecule (Fig. 8) and it was used, without Rosalind's permission, by J. Watson and F. Crick to interpret completely the structure of DNA molecule using also Chargaff's results leading to the correct A-U and A-C pairings, which were consistent with the existing data [37]. It became obvious that such a structure with precise sequence of the bases is the genetic code. An implication of such knowledge was recognized by the Nobel Prize 1962. This discovery was the milestone not only in crystallography, but also in biology. New scientific disciplines have emerged from it: structural molecular biology, molecular genetics, epigenetics and many others. At the same time this very discovery initiated many further researches in biology, medicine, forensics, pharmacology, agronomy, biotechnology, geology, anthropology and others.
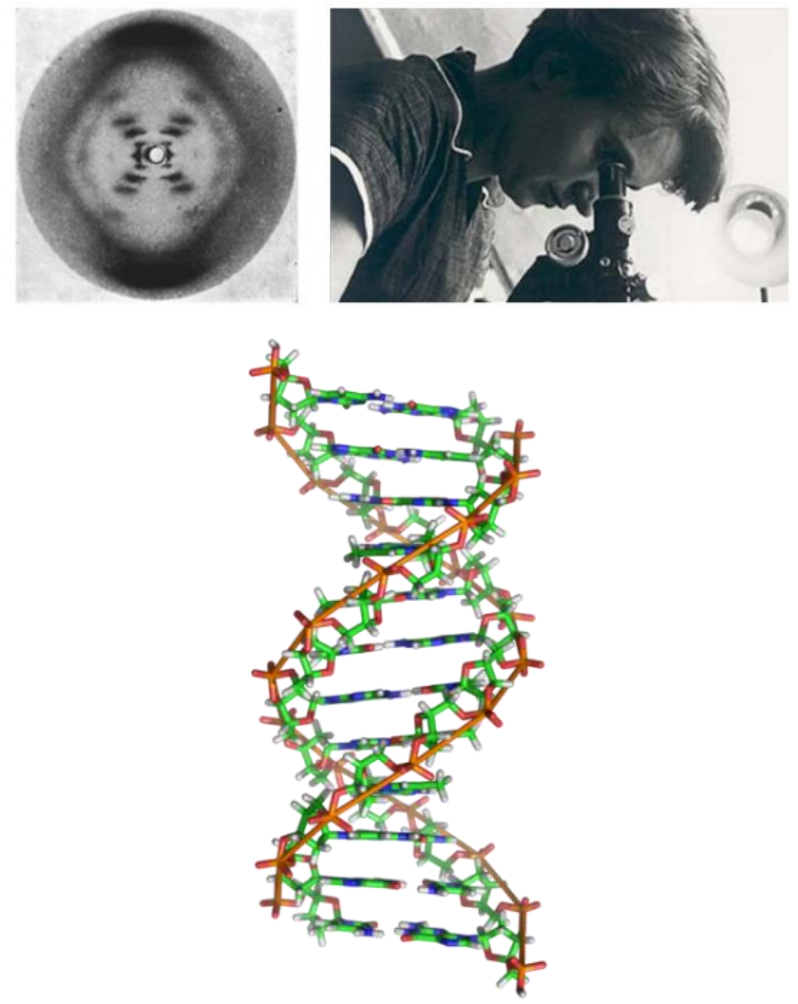

Fig. 8. Experimental evidence of helical structure of DNA originates from the work of Rosalind Franklin, based on the 'photo 51 ' and enables the epochal discovery of the $20^{\text {th }}$ century.

Chronologically, in 1965 followed the structure determination of the second protein and the first enzyme, lysozyme by D. C. Philips, whereas the mechanism of its catalyses has been the subject of a debate almost a half of the century. Thus, it is very good research project on a dynamic study by XFEL method.

In the early fifties of the last century mathematical methods for determination of phases of structure factors, based on algebraic and probability methods, were intensified by urgent needs in structure determinations of large and more complex molecules (Fig. 9). The development of mathematical methods in crystallography, assisted by efficient algorithms, has contributed to speed up the procedures for structure determinations. The key publication was the monograph Phase problem, I: Centrosymmetric Crystal, by H. Hauptman and J. Karle [38].

About seventies of the last century, parallel to the progress of computers, the first efficient software packages written by J. Stewart and S. R. Hall have been available, and then followed those ones by M. Woolfson, P. Main, G. Sheldrick, C. Giacovazzo, and E. Dodson. Together with other significant improvements of experimental techni- 
ques, such as synchrotrons and the most recently, free electron X-ray lasers, macromolecular crystallography has succeeded to reveal essential biological processes in living cells and to show how "mini-factories" such as "molecular machines" operate in our bodies. Among many of sensational results of structure determinations are the structures of plant viruses [39-41] and then human viruses such as HIV and adenovirus (Fig. 10). A. Klug was among the first who recognized DNA/RNA and proteins as constitutional macromolecular complexes of chromatin and viruses [40-42]. For the structural elucidation of these complexes A. Klug won the Nobel Prize in 1982. Among the Klug's co-workers was R. Franklin [41]. Human adenovirus is one among the largest molecular assemblies (150 MDa) determined by Xray structure analysis (3.5 ̊́ resolution) [43]. Molecular architecture of such assemblies is vital in understanding interactions of viruses and hostcells, and in design of vaccines and drugs.
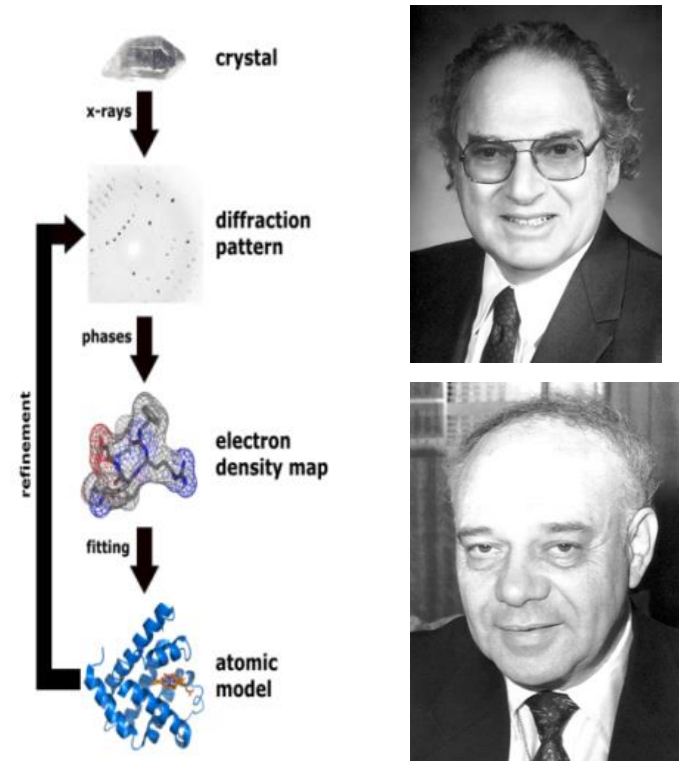

Fig. 9. A diagram showing the procedures in determination of a crystal structure. The Nobel Prize 1985 in chemistry was awarded to H. Hauptman and J. Karle "for their outstanding achievements in the development of direct methods for the determination of crystal structures".

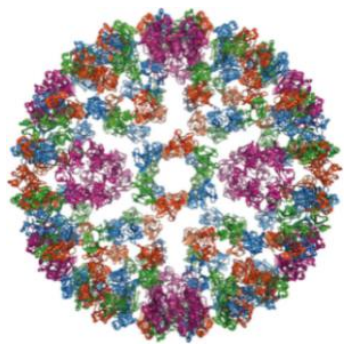

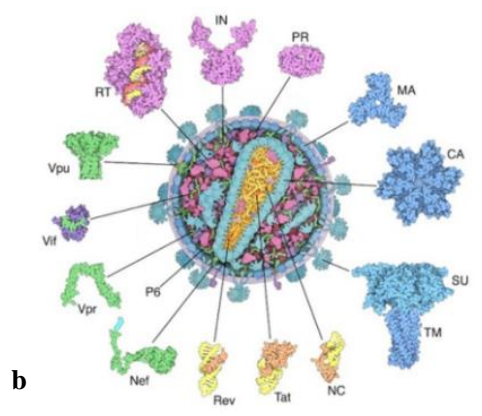

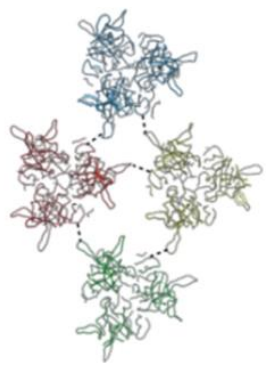

Fig. 10. a) The first virus structure was determined at atomic resolution by Harrison and coworkers in 1978 [39]. b) The research on HIV (human immunodeficiency virus) is lasting over three decades; HIV is composed of two strands of RNA, 15 types of viral proteins, and a few proteins from the last host cell it infected, all surrounded by a lipid bilayer membrane. Together, these molecules allow the virus to infect cells of the immune system and force them to build new copies of the virus. Each molecule in the virus plays a role in this process, from the first steps of viral attachment to the final process of budding (Protein Databank www.rcsb.org). c) The structure of human adenovirus, the largest molecular complex determined by X-ray structure analysis, that is essential for therapy. Schematic drawing of an adeno-virus. Interaction of variable protein parts which help stabilisation of the capside is shown at far right [43].

Discoveries of "molecular machines" explained the key mechanisms of a living cell. Among molecular machines essential in life of a cell is chromatin [42, 44-46] playing a crucial role in gene regulation; it is involved in transcription, replication, recombination and repair. Understanding its role in a cell cycle is of the outmost importance in biology. The structure of chromatin depends on the type of a cell and also on its cycle. Highly expressed dynamics of chromatin accompanied by significant conformational changes is the very demanding subject of a research (Fig. 11), which has taken over hundred years and won six Nobel prizes since then. In chromatin research con- tributed A. Klug [42] and R. D. Kornberg [44, 45]. It is an open story which will be tackled by femtosecond crystallography.

Together with the discovery of DNA double helix, the structure of chromatin, the structure of RNA polymerase II complex (prior to initial phase of transcription) and ribozyme structure circled the most important cycle of structural molecular biology. These discoveries won Nobel prizes. In 2006 R. Kornberg's structure determination of RNA polymerase II complex of eukaryotes, provided an explanation of transcription process at the molecular level (Fig. 12) [47]. 


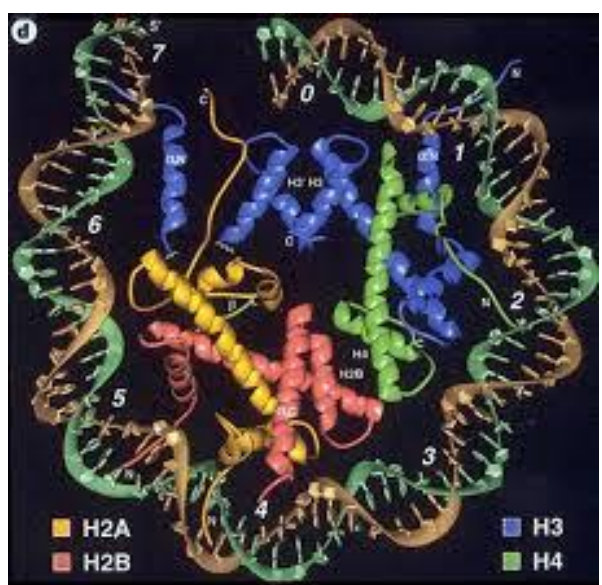

Fig. 11. Nucleosome, a core particle of chromatin shows how the histone protein octamer (two copies of each histone protein, H2A, $\mathrm{H} 2 \mathrm{~B}, \mathrm{H} 3$ and $\mathrm{H} 4$ ) is enveloped by $147 \mathrm{bp}$ DNA. The repeating nucleosome cores further assemble into high ordered structures, stabilized by the linker histone H1 (the resolution of $2.8 \AA$ ) [46].

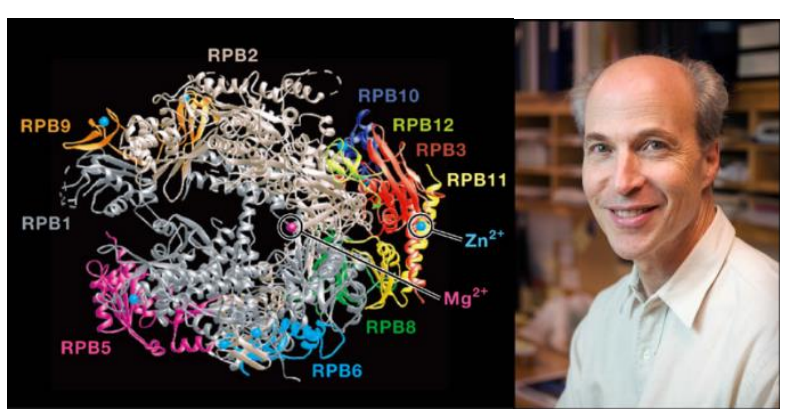

Fig. 12. The molecular structure of RNA polymerase II complex from yeast, the resolution of $2.8 \AA$, lacking the two subunits. The thirty years of R. D. Kornberg's research was recognized by the Nobel Prize in chemistry 2006. It explains genetic information transcription into mRNA, recognized by ribozyme to synthetize a protein [47].
The discovery of ribozyme structure complex revealed the enzymatic function of the complex in the synthesis of protein in a cell. This discovery showed that Darwin's theory of evolution is valid at the atomic level. Knowledge gained from the mechanisms of synthesis should help to resolve a problem of antibiotic resistance. More than thirty years persistent work of three teams ended by Nobel Prize in chemistry 2009 awarded to V. Ramakrishnan, T. Steiz, and A. Yonath (Fig. 13) [48].

In macromolecular crystallography most of the key researches spanned more than thirty years no matter of technological level of the time of discoveries. Very well hidden secrets of Nature and sometimes a lack of sophisticated technical equipment can be an obstacle on the way to the successful end. The most recent results on the structures and dynamics of G-coupled receptors (GCPR), molecular machines, belonging to a highly diverse superfamily of eukaryotic membrane proteins are based on the work spanning over two decades. The high mobility of these protein complexes is an intrinsic property, making their crystallizations almost impossible tasks. Among many difficulties and obstacles such as biochemical instability of purified GCPR proteins in detergents, structural flexibility, and the paucity of polar surface for forming crystal lattice had to be resolved; the developments included protein engineering to decrease protein heterogeneity, enhance stability, reduce flexibility and increase the polar surface available for crystal lattice formation.
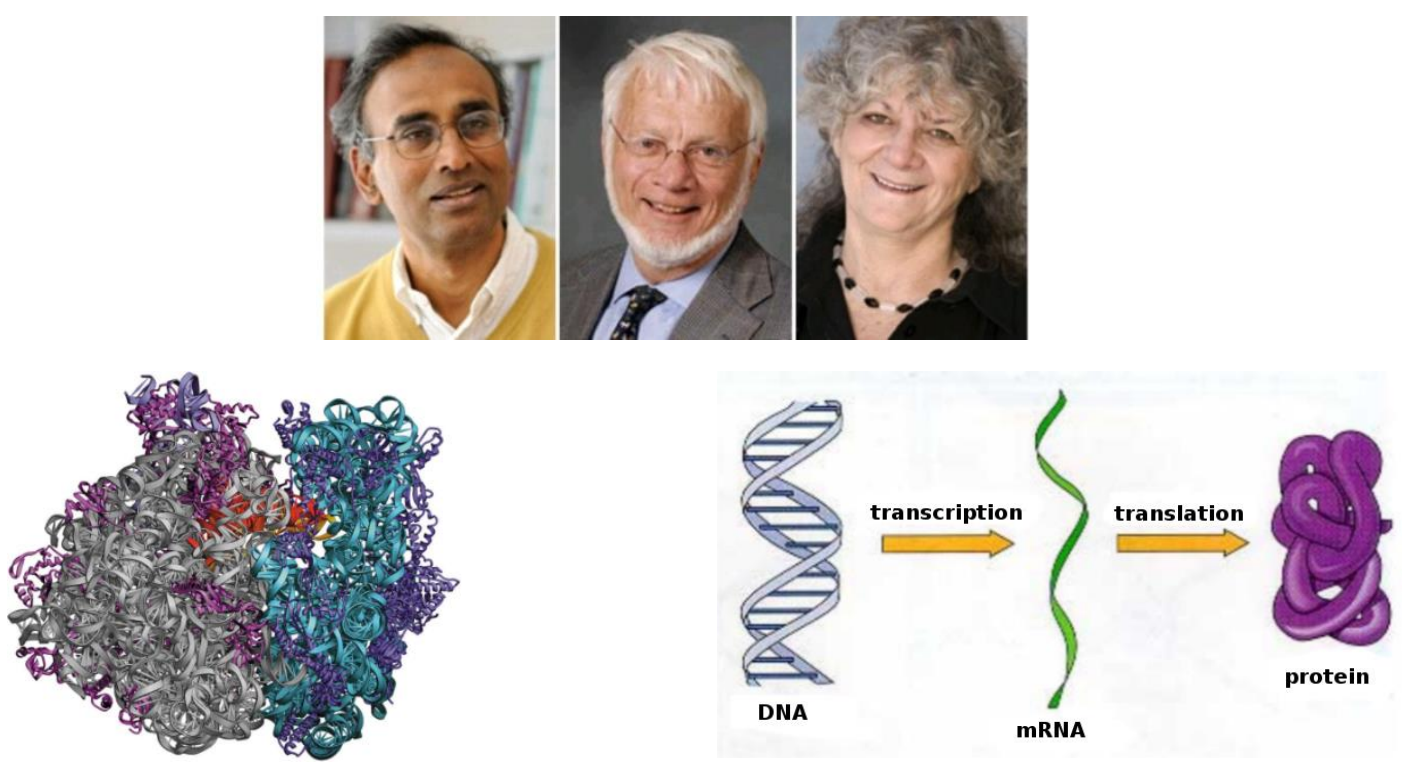

Fig. 13. The persistent research over more than thirty years brought to light the structures of small and large subunits of ribozyme at the atomic resolution and the Nobel Prize in chemistry 2009 was awarded to V. Ramakrishnan, Th. Steitz and Ada Yonath [48]. 
The development of lipid mesophase crystallography, a critical approach for membrane proteins, and the development of conformationally selective antibodies to increase polar surface available for crystal lattice formation and stabilize specific receptor conformations, put forward crystallography of membrane proteins. B. K. Kobilka [49] and R. J. Lefkowitz [50] successfully solved all these problems and started a new era of GPCR structural and chemical biology of signalling. They got an image of the receptor at the very moment when it transfers the signal from the hormone on the outside of the cell to the G-protein on the inside of the cell (Fig. 14). Their work was awarded by Nobel Prize 2012 in chemistry. In humans there are about 800 GPCRs, which interact with big variety of extracellular signalling molecules involved in a cell communication by coupling to heterotrimeric G-protein complex. So far, the structures of 22 receptors were solved. Understanding the structures and dynamics of this important class is of outmost importance in drug design. The most recent innovation, femtosecond crystallography, meets all requirements and it is already in use [51].
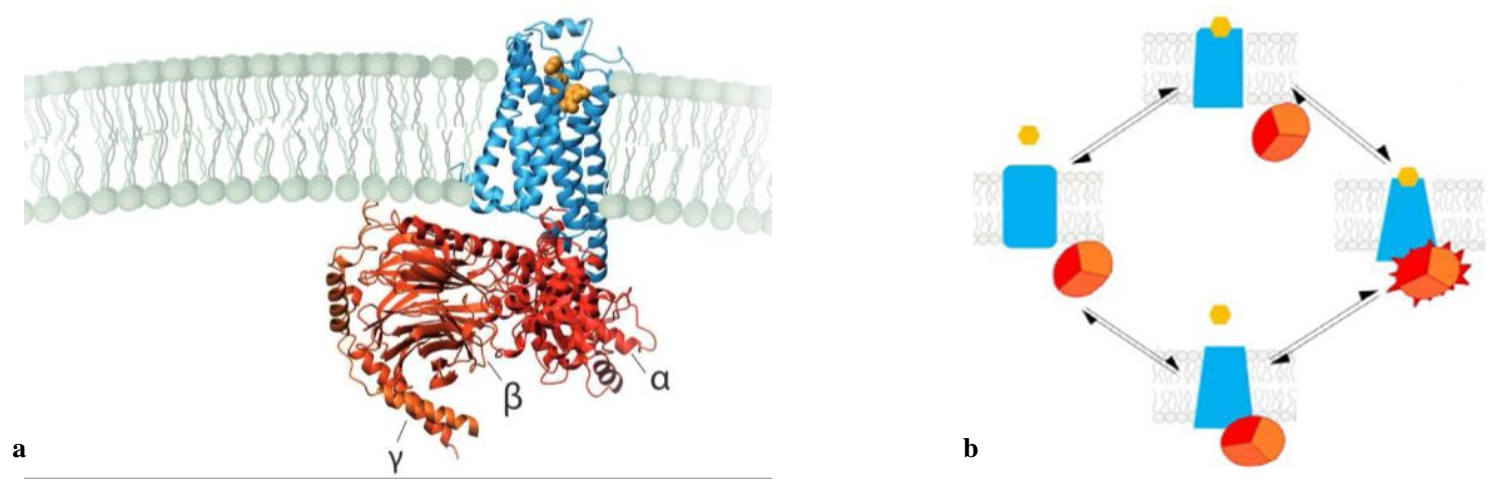

Fig. 14. Life needs flexibility. a) The active heterotrimeric complex of G-protein (red), receptor (blue), and a sensor- a hormone (yellow) during the cell signalisation. b) Its high mobility with conformational changes and thermodynamic cycle.

\section{PROSPECTS}

"The long term predictions in science are hopeless and even short-term predictions are usually wrong", Kleppner's words on the $50^{\text {th }}$ anniversary of the journal Physics Today [52] come along with the W. L. Bragg's statement given in 1968: "In many cases this new knowledge has led to a fundamental revision of ideas in other branches of science and all the expectations are more than fulfilled" [22]. The new era of chemical biology has already started and it is in the permanent progress. The structures of molecular machines crucial for a cell life and dynamics of cell processes (Figs. 15a [53-55] and $15 b[56,57])$ already started to be examined by the most recent technical achievements - free electron X-ray lasers.
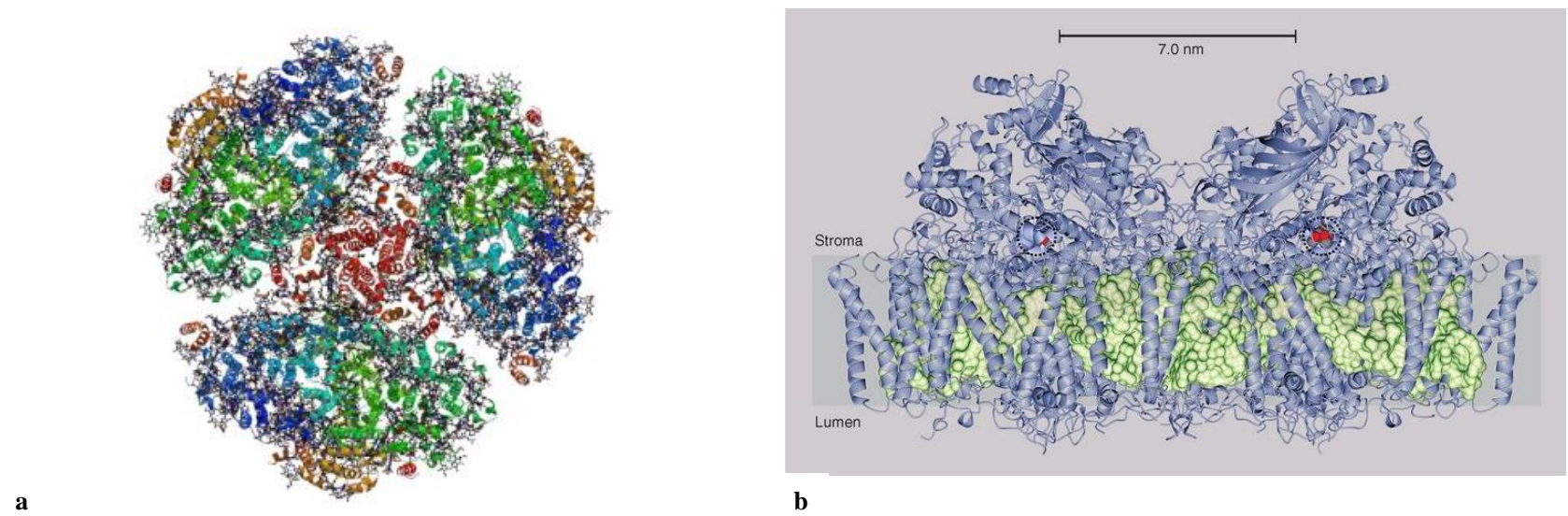

Fig. 15. New era of chemical biology is marked by structures of molecular 'machines' essential in life cycle of cells such as a) the trimer of photosystem I [53-55] and b) photosystem II at $1.9 \AA$ resolution, protein is shown in blue and the chlorophyl in green, membrane bilayer is indicated as shaded area and oxygen - metal cluster is depicted as spheres in red [56, 57]. The results of research on their structural and dynamic characteristics are bioinspiring models for inventing systems for production of 'green energy'. 
Femtosecond serial crystallography (XFEL) gives insight into ultrafast biochemical reactions at the atomic level. Together with the XFEL exploitation, information from complementary methods such as microscopies of high resolution, various spectroscopies, molecular modelling and bioinformatics, will give a hybrid model based on dynamics of the system. Thus, in twenty years a molecular model of living cell can be expected [58-60].

Protein structures are targets for drugs. The most recent results on the intensive research related to Ebola disease and HIV illustrate (Fig. 16) [61, 62] deep involvement of X-ray crystallography in the solution of the most urgent problems of the human health. The intensive research on GCPR membrane proteins (Fig. 14) is of the prime interest to pharmaceutical industry but also for brain research.

The flood of new functional materials of a wide range of applications from medicine, (bio)analytics, to molecular electronics (Fig. 15 [53-55] and $[56,57])$, new computers, and for a time being, unreachable quantum computers, makes unthinkable possibilities (Fig. 17) [63, 64]. Graphene, DNA chips or biosensors are on the way to revolutionize almost all aspects of our lives. Syntheses of natureinspired molecules and an imitation of biological processes of molecular machines are on the way to offer new efficient and ecologically friendly functional materials that might look to someone as a science fiction.
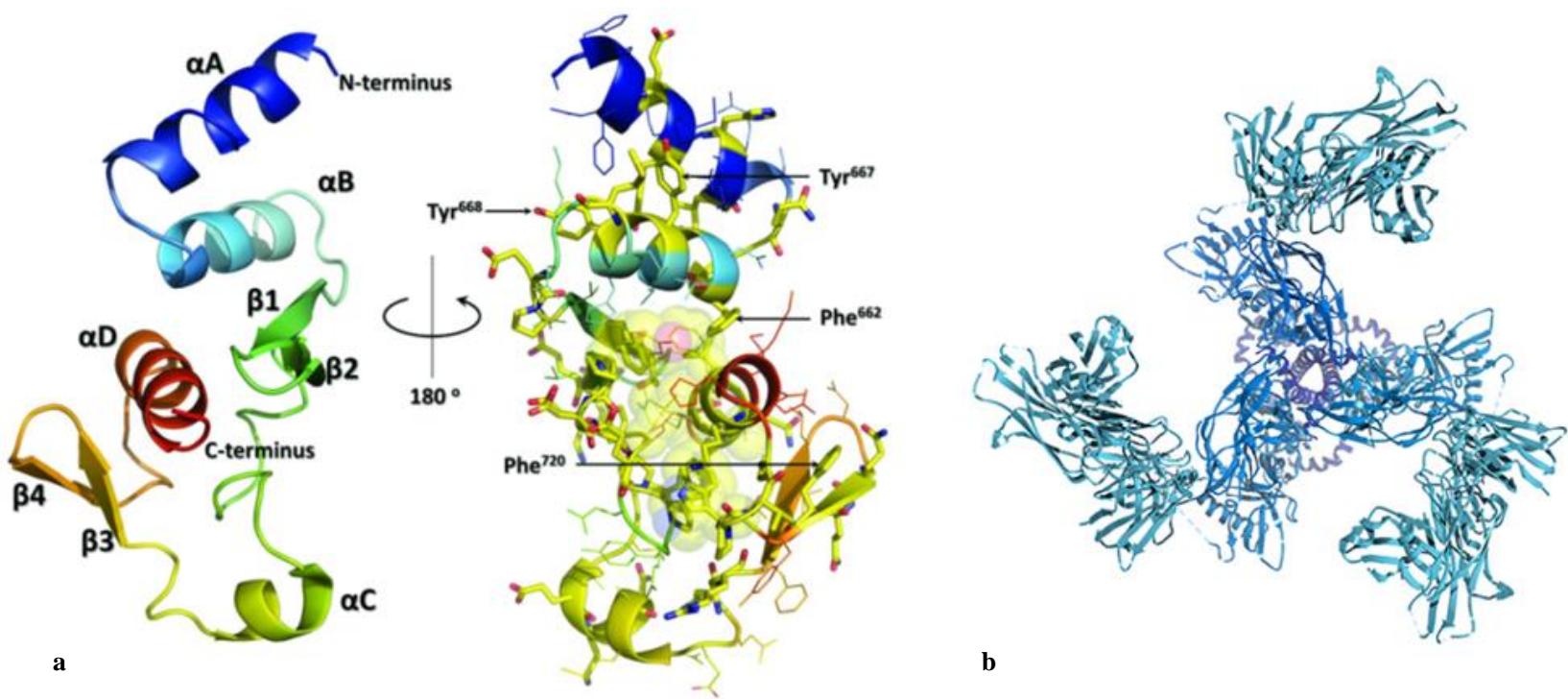

Fig. 16. Protein structures as drug targets for novel medications: a) nucleo-protein, having new folding type, with its C-terminal domain, responsible for replication of Zaire Ebola virus [61]; b) soluble protein of HIV- envelope active in invading host immune cells [62].

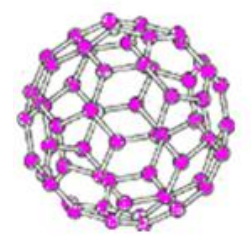

a

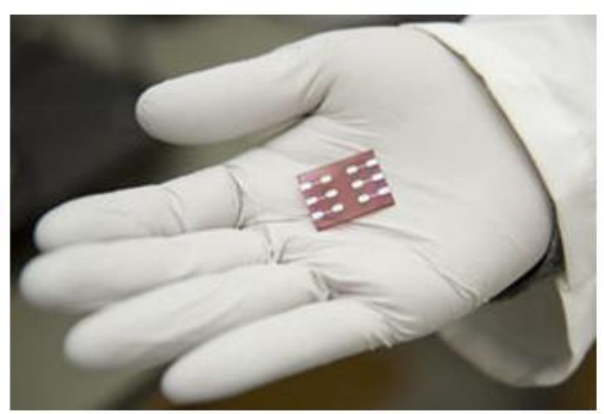

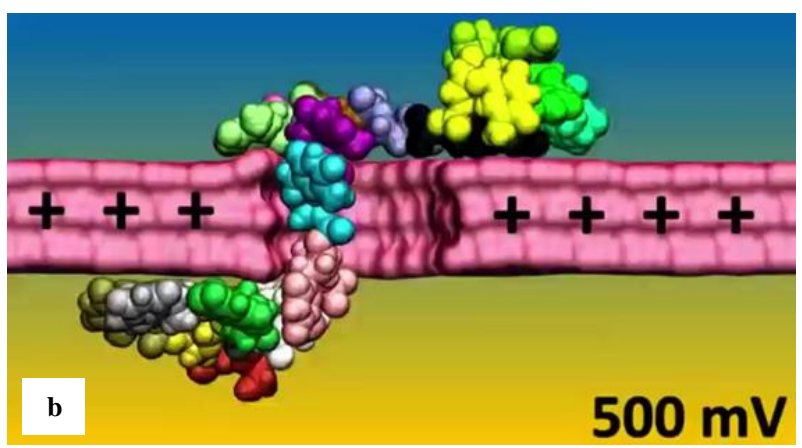

Fig. 17. Prospects - a road to unimaginableness: preparation of functional materials combining functional domains of two or more molecules. a) Solar cells contain fullerene molecules and bind PID2 polymer, which amplify solar effect [63]; b) charged graphene gives DNA a stage to perform molecular gymnastics: threading a DNA molecule through a tiny hole, called a nanopore, in a sheet of graphene allows researches to read DNA sequences. Positive charge speeds up DNA movement through the nanopore, whereas a negative charge stops the DNA in its tracks. During these movements DNA changes its conformation. It is even possible to observe the conformational change when nucleotide is methylated, a tiny chemical change can turn a gene on or off. It is obvious that such a DNA (reversible) performance can be used in DNA sequencing for personalized medicine [64]. 


\section{REFERENCES}

[1] E. S. Fedorov, Nature and Science, Priroda, 4, 425-432 (1917).

[2] W. C. Röntgen, Über eine neue Art von Strahlen, Sitzungber. Phys. Med. Ges. Würzburg 137, 132-141 (1895).

[3] M. Laue, Eine quantitative Prüfung der Theorie für die Interferenze-Erscheinungen bei Röntgenstrahlen, Sitzungsber. K. Bayer. Akad. Wiss. Muenchen, 363-373 (1912)

[4] W. Friedrich, P. Knipping, and M. Laue, InterferenzErscheinungen bei Röntgenstrahlen, Sitzungsber. K. Bayer. Akad. Wiss. Muenchen, 303-322 (1912).

[5] W. L. Bragg, The diffraction of short electromagnetic waves by a crystal, Nature, 90, 410-410 (1912).

[6] W. L. Bragg, The Structure of Some Crystals as Indicated by Their Diffraction of X-rays, Proc. R. Soc. Lond. A, 89, 248-277 (1913).

[7] W. H. Bragg, W. L. Bragg, The Structure of diamond, Proc. R. Soc. London A 89, 277-291 (1913).

[8] W. H. Bragg, W. L.Bragg, The reflection of X-rays by crystals, Proc. R. Soc. London A 88, 428-438 (1913).

[9] W. H. Bragg, X-rays and crystal structure, Philos. Trans. R. Soc. London, A 215, 253-274 (1915).

[10] B. Kojić-Prodić, J. Kroon, (Bio)crystallography at the turn of Millenium, Croat. Chem. Acta, 74, 1-35 (2001) and references therein.

[11] B. Kojić-Prodić, K. Molčanov, Stogodišnjica rendgenske kristalografije, Kem. Ind. 62, 247-260 (2013).

[12] D. Swarzenbach, The success story of crystallography, Acta Cryst. A68, 57-67 (2012).

[13] D. Bourgeois, F. Schotte, M. Brunori, B. Vallone, Time-resolved methods in biophysics. 6. Time resolved Laue crystallography as a tool to investigate photo activated protein dynamics, Photochem. Photobiol. Sci. 6, 1047-1056 (2007).

[14] M. R. V. Jørgensen, V. R. Hathwar, N. Bindzus, N. Wahlberg, Y.-S. Chen, J. Overgaard, B. B. Iversen, Contenporary $\mathrm{X}$-ray electron-density studies using synchrotron radiation IUCrJ 1, 267-280 (2014).

[15] R. F. Stewart, Electron population analysis with rigid pseudoatoms, Acta Cryst. A32, 565-574 (1976).

[16] F. L. Hirshfeld, Bonded-Atom Fragments for Describing Molecular Charge Densities, Theor. Chim. Acta 44, 129-138 (1977).

[17] N. K. Hansen, P. Coppens, Testing aspherical atom refinements on small-molecule data sets, Acta Cryst. A34, 909-921 (1978).

[18] G. R. Desiraju, J. J. Vittal, A. Ramanan, Crystal Engineering, A Textbook, World Scientific Publishing, Singapore, 2011.

[19] M. Deutsch, B. Gillon, N. Claiser, J.-M. Gillet, C. Lecomte, M. Souhassou, First spin-resolved electron distribution in crystals from combined polarized neutron and X-ray diffraction experiments, IUCrJ 1, 194199 (2014).
[20] H. N. Chapman, Protein crystallography using X-ray free-electron lasers, SPIE Newsroom, 10.1117/ 2.1201302.004713.

[21] H. N. Chapman, P. Fromme, A. Barty, T. A. White, R. E. Kirian, A. Aquila, M. S. Hunter, et al., Femtosecond X-ray protein nanocrystallography, Nature, 470, 73-77 (2011).

[22] W. L. Bragg, X-ray crystallography, Sci. Am. 219, 5870 (1968).

[23] J. A. Le Bel, Bull. Soc. Chim. Fr. 22, 337-347 (1874).

[24] J. H. van't Hoff, La chimie dans l'espace, Bazendijk, Rotterdam, 1875.

[25] E. Fischer, Ber. Dtsch. Chem. Ges. 24 (1891) 18361845.

[26] E. Fischer, Ber. Dtsch. Chem. Ges. 24, 2683-2687 (1891).

[27] J. M. Bijvoet, Phase determination in direct Fouriersynthesis of crystal structure, Proc. K. Ned. Akad. Wet. 52, 313-314 (1949)

[28] J. C. Randel, F. C. Niestemski, A. R. Botello-Mendez, W. Mar, G. Ndabashimiye, S. Melinte, J. E. P, Dahl, R. M. K. Carison, E. D. Butova, A. A. Fokin, P. R. Schreiner, J.-Ch. Charlier, H. C. Manoharan, Unconventional molecule-resolved current rectification in diamond-fullerene hybrids, Nature Commun. 5:4877 doi 10.1038/ncomms5877 (2014).

[29] J. D. Bernal, The structure of graphite, Proc. R. Soc. London, A 106, 749-773 (1924).

[30] K. S. Novoselov, A. K. Geim, S. V. Morozov, D. Jiang, Y. Zhang, S. V. Dubonos, I. V. Grigorieva, A. A. Firsov, Electric field in atomically thin carbon films, Science, 306, 666-669 (2004).

[31] K. Lonsdale, The structure of the benzene ring in $\mathrm{C}_{6}\left(\mathrm{CH}_{3}\right)_{6}$, Proc. R. Soc. Lond., A, 123, 494-515 (1929).

[32] D. Crowfoot Hodgkin, C. W. Bunn, B. W. Rogers-Low, A. Turner-Jones, The X-ray Crystallographic Investigation of the Structure of Penicillin, Oxford University Press, Oxford, 1949.

[33] A. L. Patterson, Fourier series method for the determination of the components of interatomic distances in crystals, Phys. Rev. 46, 372-376 (1934).

[34] D. W. Green, V. M. Ingram, M. F. Perutz, The structure of haemoglobin. IV. Sign determination by the isomorphous replacement method, Proc. Royal Soc. Lond., A 225, 287-307 (1954).

[35] M. F. Perutz, M. G. Rossmann, A. F. Cullis, H. Muirhead, G.Will, A. C. T North, Structure of hemoglobin: a three-dimensional Fourier synthesis at $5.5 \AA$ resolution, obtained by X-ray analysis. Nature 185, 416-422 (1960).

[36] R. Franklin, R. G. Gosling, Molecular structure for deoxypentose nucleic acid, Nature, 171, 740-741 (1953).

[37] J. D.Watson, F. H. C. Crick, A Structure for deoxyribose nucleic acid, Nature 171, 737-738 (1953).

[38] H. Hauptman, J. Karle, Solution of the Phase Problem. I. The Centrosymmetric Crystal, ACA Monograph No. 3, Polycrystal Book Service, 1953. 
[39] S. C. Harrison, A. J. Olson, C. E. Schutt, F. K. Winkler, G Bricogne, Tomato Bushy stunt virus at $2.9 \AA$ resolution, Nature, 276, 368-373 (1978).

[40] D. L. D. Caspar, A. Klug, Physical principles in the construction of regular viruses, Cold Spring Harb. Symp. Quant. Biol. 27, 1-24 (1962).

[41] A. Klug, J. T. Finch, R. E. Franklin, The structure of turnip yellow mosaic virus: X-ray diffraction studies, Biochim. Biophys. Acta 25, 242-251 (1957).

[42] F. Thoma, T. Koller, A. Klug, Involvement of histone $\mathrm{H} 1$ in the organization of the nucleosome and of the salt-dependent superstructures of chromatin. J. Cell Biol. 83, 403-427(1979).

[43] G. R. Nemero, P. L. Stewart, V. S. Reddy, V. S., Structure of human adenovirus, Curr. Opin. Virol. 2, 115121 (2012).

[44] R. D. Kornberg, Chromatin structure: a repeating unit of histone and DNA, Science, 184, 868-871 (1974).

[45] R. D. Kornberg, J. O. Thomas, Chromatin structure; Oligomers of the histones, Science, 184, 865-868 (1974).

[46] K. Luger, A. W. Mäder, R. K. Richmond, D. F. Sargent, T. J. Richmond, Crystal structure of the nucleosome core particle at $2.8 \AA$ resolution, Nature 389, 251-260 (1997).

[47] P. Cramer, D. A. Bushnell, R. D. Kornberg, Structural basis of transcription: RNA polymerase II at $2.8 \AA$ resolution, Science 292, 1863-1876 (2001).

[48] The Noble Prize in Chemistry. URL: www.nobelprize. org/nobel_prizes/chemistry/

[49] B. R. Kobilka et al., Crystal structure of the $\beta_{2}$ adrenergic receptor - Gs protein complex, Nature, 477, 549555 (2011)

[50] A. de Lean, J. Stadel, R. L. Lefkowitz, A ternary complex model explains the agonist-specific binding properties of the adenylate cyclase-coupled $\beta$-adrenergic receptor, J. Mol. Chem. 255, 7108-71177 (1980).

[51] V. Cherezov et al., Serial femtosecond crystallography of G protein-coupled receptors, Science 342, 15211524 (2013)

[52] D. Kleppner, Physics in 50 years, Phys. Today 51, 1111 (1998).

[53] N. Klauss, W.-D. Schubert, O. Klukas, P. Fromme, H. T. Witt, W. Saenger, Photosystem I at $4 \AA$ resolution represents the first structural model of aa joint photosynthetic reaction centre and core antenna system, $\mathrm{Na}$ ture Struct. Biol. 3, 965-973 (1996).

[54] I. Grotjohann, P. Fromme, Structure of cyanobacterial photosystem I, Photosynthesis Research 85 51-72 (2005).

[55] M. Watanabe, D. A. Semchonok, M. T. WebberBirungi, S. Ehira, K. Kondo, R. Narikawa, M. Ohmora, E. J. Boekema, M. Ikeuchi, Attachement of phycobilisomes, In antenna-photosystem I Supercomplex of cyanobacteria, PNAS 111, 2512-2517 (2014).

[56] K. N. Ferreira, T. M. Iverson, K. Maghlaoul, J. Barber, S. Iwata, Architecture of the photosynthetic oxygenevolving center, Science, 303, 1831-1838 (2004).

[57] M. Suga, F. Akkita, K. Hirata, G. Ueno, H. Murakami, Y. Nakajima, T. Shimizu, K. Yamashita, M. Yamamoto, H. Ago, J.-R. Shen, Native structure of photosystem II at $1.95 \AA$ resolution viewed by femtosecond X-ray pulses, Nature 517, 99-103 (2015).

[58] K. Lasker, F. Förster, S. Bohm, T. Walzthoeni, E. Villa, P. Unverdorben, F. Beck, R. Aebersold, A. Sali, W. Baumeister, Molecular architecture of the $26 \mathrm{~S}$ proteasome holocomplex determined by an integrative approach, PNAS, 109, 1380-1387 (2012).

[59] E. Callaway, Data bank struggles as protein imaging ups its game, Nature, 514, 416 (2014).

[60] G. Kleywegt et al., 3D cellular context for the macromolecular world, Nature Struct. Mol. Biol. 21, 841-845 (2014).

[61] P. J. Dziubańska, U. Derwenda, J. F. Ellena, D. A. Engel, Z. S. Derewenda, The structure of the C-terminal domain of the Zaire ebola virus nucleoprotein, Acta Cryst. D70, 2420-2429 (2014).

[62] J.-P. Jullien, A. Cupo, D. Sok, R. L. Stanfield, D. Lyumkis, M. C. Deller, P.-J. Klasse, D. R. Barton, R. W. Sanders, J. P. Moore, A. B. Ward, I. A. Wilson, Crystal Structure of a Soluble Cleaved HIV-1 Envelope Trimer, Science, 342, 1477-1483 (2013).

[63] L. Lu, T. Xu, W. Chen, E. S. Landry, L. Yu, Nature Photonics, 8, 716-722 (2014).

[64] M. Shankla, A. Aksimentiev, Conformational transitions and stop-and-go nanopore transport od singlestranded DNA on charged graphene, Nature Commun. 5, 5171 (2014). 